\section{Direct PCR Amplification of HCV RNA from Human Serum}

\author{
Antonella Ravaggi, \\ Daniele Primi, and \\ Elisabetta Cariani
}

Consorzio per le Biotecnologie, Consiglio Nazionale delle Ricerche (CNR), Institute of Chemistry, School of Medicine, University of Brescia, 25123 Brescia, Italy
Hepatitis $\mathrm{C}$ virus (HCV) is a positivestranded RNA virus responsible for most cases of parenterally transmitted non-A, non-B hepatitis (NANBH). ${ }^{(1,2)}$ The polymerase chain reaction ( $\mathrm{PCR}$ ) is, at present, the only method allowing the detection of $\mathrm{HCV}$ RNA in biological specimens, thus providing the direct appraisal of infectivity. (3) Therefore, serum HCV RNA determination ideally represents the method of choice for the prevention of $\mathrm{HCV}$ transmission. The routine clinical use of PCR-based technology, however, is seriously hampered by technical difficulties. In the case of HCV infection, one of the main obstacles is the necessity of extracting viral RNA before amplification, a time-consuming step that requires RNase-free conditions that are difficult to obtain in diagnostic laboratories.

Here we describe a simple and rapid method for reverse transcription (RT)PCR amplification of HCV RNA from human serum that does not require the RNA extraction step. After denaturation ( $30 \mathrm{sec}$ at $92^{\circ} \mathrm{C}$ ), $3 \mu \mathrm{l}$ of serum was directly added to the RT $\mathrm{mix}(50 \mathrm{~mm}$ Tris $\mathrm{HCl}, \mathrm{pH} 8.2,70 \mathrm{~mm} \mathrm{KCl}, 10 \mathrm{~mm}$ $\mathrm{MgCl}_{2}, 4 \mathrm{~mm}$ DTT, 12 units of human placental ribonuclease inhibitor (HPRI), $0.4 \%$ Nonidet P-40, 50 pmoles of a specific antisense primer (A1), $250 \mu \mathrm{M}$ dNTPs, 6 units of AMV-RT, in a final volume of $25 \mu \mathrm{l}$ ). RT was carried out at $42^{\circ} \mathrm{C}$ for $60 \mathrm{~min}$, and the cDNA was added directly, after denaturation (5 min at $100^{\circ} \mathrm{C}$ ), to the PCR mix. Amplification was performed following the nested primers protocol, ${ }^{(4)}$ as previously described, (5) with two sets of primers located in the $5^{\prime}$ untranslated region (UTR) of the viral genome. The first round of PCR (35 cycles) was carried out using primers A1 (5' GATGCACGGTCTACGAGACCTC-3 ') and $\mathrm{S} 1\left(5^{\prime}\right.$-AACTACTGTCTTCACGCAGAA-3'), generating a PCR product of $289 \mathrm{bp}$. For the second round (25 cycles), we used primers A2 (5' GCGACCCAACACTACTCGGCT-3') and S2 (5'-ATGGCGTTAGTATGAGTG-3'), generating a PCR product of $187 \mathrm{bp}$. PCR cycles were as follows: denaturation at $94^{\circ} \mathrm{C}$ for $1 \mathrm{~min}$, annealing of primers at $45^{\circ} \mathrm{C}$ for $1 \mathrm{~min}$, and elongation at $72^{\circ} \mathrm{C}$ for $2 \mathrm{~min}$.

This method was used to screen serial serum samples collected from a patient with post-transfusion NANBH. In this patient, positivity for the antiHCV ELISA assay (Ortho Diagnostics), detecting antibodies against the nonstructural viral antigen C-100, was first observed 13 weeks after transfusion. By contrast, the detection of the viral nucleic acid was possible as soon as 3 weeks after transfusion (Fig. 1, lane b), confirming the superior sensitivity of PCR for early diagnosis of acute NANBH. ${ }^{(3,4)}$ Further prelevments, collected 5-56 weeks after transfusion, confirmed persistent positivity for HCV RNA.

Comparison of direct amplification from serum (Fig. 1, part 1) with the standard procedure (RNA extraction ${ }^{(6)}$, RT-PCR) (Fig. 1, part 2), performed on equivalent amounts of template, showed a perfectly comparable sensitivity. By both methods, we obtained amplification products easily visible on agarose gel from all samples. The very low circulating HCV titers present in most of patients represent a major problem for the determination of the viral nucleic acids in serum samples. The present method for direct $\mathrm{HCV}$ RNA determination was successfully performed using up to $12 \mu \mathrm{l}$ and down to $1 \mu \mathrm{l}$ of a $1: 10^{4}$ dilution of a positive control serum. This indicates that the high sensitivity of this PCR protocol allows the detection of circulating $\mathrm{HCV}$ particles in a wide range of concentration.

An important drawback for the clinical use of HCV RNA amplification is the extreme variability of the viral genome, especially in the regions encoding the envelope viral proteins. The observation of conserved mutations among American and Japanese isolates suggested the existence of HCV subtypes segregated in different geographic areas. ${ }^{(3)}$ The choice of oligonucleotide primers located in highly conserved genomic regions, such as the $5^{\prime}$ UTR, ${ }^{(3)}$ is therefore critical for a clinically useful PCR protocol. By comparative nucleotide sequence analysis of variable regions, we recently detected the common distribution in our geographic area of HCV genomes belonging to the two main subtypes (HCV-US and HCV-J) (unpublished results). Despite the presence of extensive sequence divergence in the envelope genes, $\mathrm{HCV}$ genomes belonging to 


\section{Technical TipsIIIIII}

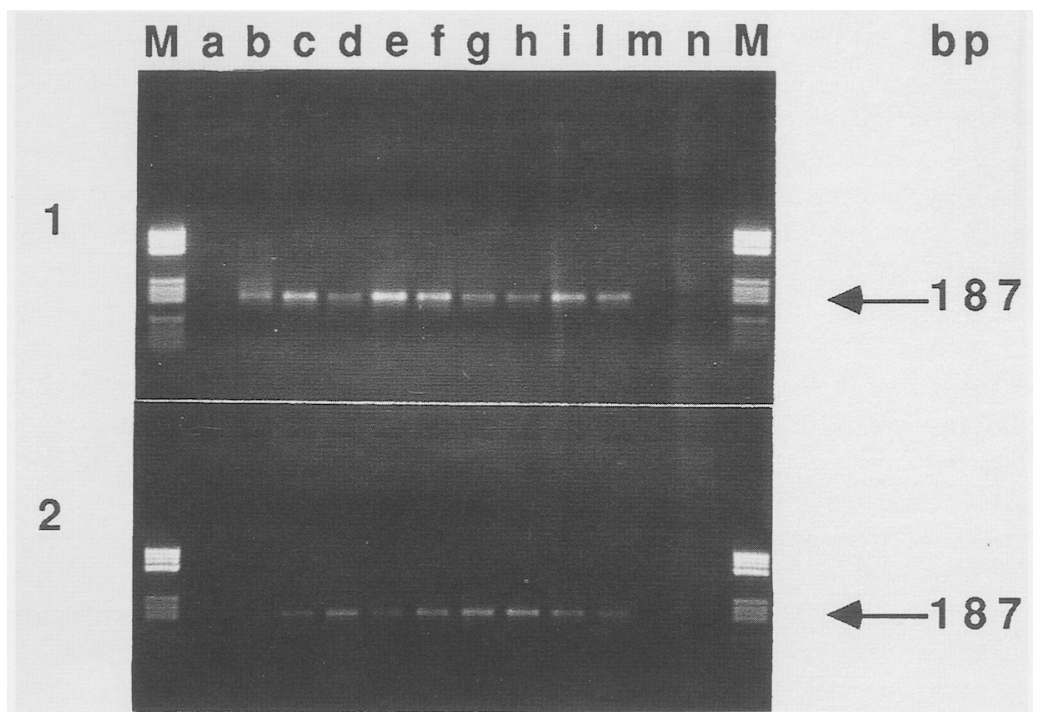

Figure 1 Detection of HCV RNA in serum samples collected from a NANBH patient. (1) RTPCR performed directly on 3- $\mu$ l serum samples. (2) RT-PCR performed on RNA extracted from equivalent amounts of the same serum samples. Twenty microliters of each PCR reaction (carried out in a $100-\mu l$ volume) was loaded onto a $1.5 \%$ agarose gel. (Lanes $a-l$ ) Serial samples from a subject with post-transfusion NANBH. Time after transfusion: (lane a) 2 weeks; (lane $b$ ) 3 weeks; (lane $c) 5$ weeks; (lane $d$ ) 7 weeks; (lane $e$ ) 10 weeks; (lane $f$ ) 13 weeks; (lane $g$ ) 15 weeks; (lane $h$ ) 18 weeks; (lane i) 25 weeks; (lane $l$ ) 56 weeks. (Lane $m$ ) Serum from a healthy blood donor; (lane $n$ ) PCR mix without CDNA; (lane $M$ ) molecular weight marker obtained from cleavage of plasmid pBR322 DNA with Hae III.

both subtypes could be amplified by the primers used in this study (data not shown), confirming the high conservation of the $5^{\prime}$ UTR sequence among different $\mathrm{HCV}$ isolates. ${ }^{(3)}$

In conclusion, we have described a simple and rapid RT-PCR protocol for the determination of $\mathrm{HCV}$ RNA that enables a bypass of the RNA extraction step. The possibility of performing RTPCR amplification directly on serum samples significantly facilitates $\mathrm{HCV}$ RNA determination on large series and should contribute to a wider application of this method in clinical laboratories.

\section{REFERENCES}

1. Choo, Q.-L., G. Kuo, A. Weiner, L.R. Overby, D.W. Bradley, and $M$. Houghton. 1989. Isolation of a cDNA clone from a blood-borne non-A, non-B viral hepatitis genome. Science 244: 359-362.

2. Choo, Q.-L., A. Weiner, L.R. Overby, G. Kuo, and M. Houghton. 1990. Hepatitis $C$ virus: The major causative agent of viral non-A, non-B hepatitis. Br. Med. Bull. 46: 423-430.

3. Houghton, M., A. Weiner, J. Han, G. Kuo, and Q.-L. Choo. 1991. Molecu- lar biology of the hepatitis $C$ viruses: Implications for diagnosis, development and control of viral disease. Hepatology 14: 381-391.

4. Garson, J.A., R.S. Tedder, M. Briggs, P. Tuke, J.A. Glazebrook, A. Trute, D. Parker, J.A.J. Barbara, M. Contreras, and S. Aloysius. 1990. Detection of hepatitis $C$ viral sequences in blood donations by "nested" polymerase chain reaction and prediction of infectivity. Lancet 335: 1419-1422.

5. Imberti, L., E. Cariani, A. Bettinardi, A. Zonaro, A. Albertini, and D. Primi. 1991. An immunoassay for specific amplified $\mathrm{HCV}$ sequences. J. Virol. Methods 34: 233-243.

6. Chomczynski, P. and N. Sacchi. 1987. Single-step method of RNA isolation by acid guanidinium-thiocyanatephenol-chloroform extraction. Anal. Biochem. 162: 156-159.

Received October 18, 1991; accepted in revised form February 12, 1992. 


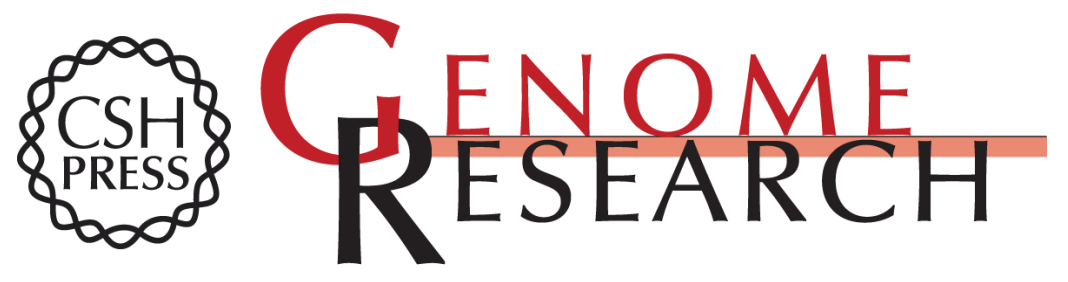

\section{Direct PCR amplification of HCV RNA from human serum.}

A Ravaggi, D Primi and E Cariani

Genome Res. 1992 1: 291-292

Access the most recent version at doi:10.1101/gr.1.4.291

References This article cites 6 articles, 1 of which can be accessed free at:

http://genome.cshlp.org/content/1/4/291.full.html\#ref-list-1

\section{License}

Email Alerting Receive free email alerts when new articles cite this article - sign up in the box at the Service top right corner of the article or click here.

\section{Affordable, Accurate Sequencing.}

To subscribe to Genome Research go to: https://genome.cshlp.org/subscriptions 